\title{
5-[Substituted]-1, 3, 4-thiadiazol-2-amines: Synthesis, Spectral Characterization, and Evaluation of their DNA interactions
}

\author{
N. Shivakumara ${ }^{\mathrm{a}, \mathrm{b}}$ and P. Murali Krishna $\mathrm{a}^{\mathrm{a}^{*}}$
}

${ }^{a}$ Department of Chemistry, Ramaiah Institute of Technology, Bangalore - 560054, India

${ }^{b}$ Visvesvaraya Technological University, Belagavi-590018, India

C H R O N I C L E

Article history:

Received March 15, 2019

Received in revised form

April 18, 2019

Accepted April 21, 2019

Available online

April 21, 2019

Keywords:

1,3, 4-Thiadiazol-2-amines

DNA interactions

DNA cleavage studies

\begin{abstract}
A B S T R A C T
The presence of heterocyclic moiety in diverse compounds, strongly indicative of the desired effect on physiological activity, and it reflects on efforts to find useful synthetic drugs. In this connection, here reporting the synthesis and characterization of 5-[substituted]-1, 3, 4thiadiazol-2-amines (1-7). All the prepared compounds were characterized by spectroscopic methods viz. ${ }^{1} \mathrm{H}-\mathrm{NMR},{ }^{13} \mathrm{C}\left\{{ }^{1} \mathrm{H}\right\}-\mathrm{NMR}$, FT-IR, and LC-MS. The results of the DNA binding interactions using absorption and fluorescence spectroscopy reveal that the compounds are avid binders to DNA. A DNA cleavage study with pUC18 DNA using gel electrophoresis indicates the compounds are able to cleave DNA in presence of oxidant $\mathrm{H}_{2} \mathrm{O}_{2}$.
\end{abstract}

(C) 2019 by the authors; licensee Growing Science, Canada.

\section{Introduction}

Recently interest in the synthesis and investigation of heterocyclic compounds forms major part of organic chemistry may be due to their vital role in the development of therapeutic drugs, industrial catalysts etc. Literature survey ${ }^{1-6}$ reveals that heterocyclic compounds containing sulphur and nitrogen have been under investigation due to their remarkable biological and industrial applications.

Among, thiadiazoles, a five-membered heterocyclic compounds containing two nitrogenand one sulphur atoms as the heteroatoms, and are exist in different isomeric forms viz.(a)1,2,3-thiadiazole (b)1,2,5-thiadiazole (c) 1,2,4-thiadiazole and (d) 1,3,4-thiadiazole ${ }^{7}$. Among, 1,3,4-thiadiazoles having more applications and exhibiting potential biological activities like insecticidal ${ }^{8,}$, fungicidal $^{10}$, ${ }^{11}$, herbicidal activity ${ }^{12}$, potent anti-cancer ${ }^{13,14}$, anti-proliferative activity ${ }^{15,16}$, Antiviral ${ }^{17}$, inhibitors of acetyl cholinesterase (AChE) and butyrylcholinesterase $(\mathrm{BuChE})^{18}$, Alzheimer ${ }^{19,20}$, and antimicrobial activities $^{21}$. 1,3,4-thiadiazoles also used in electrical and optical ${ }^{22}$, liquid crystal $^{24-26}$, corrosion inhibitors $^{27}$, in dye preparation ${ }^{28}$. The literature survey reveals that various thiadiazoles are the part of many potential drugs (Fig. 1) and exhibiting the wide spectrum of pharmacological activities and the biological activity of 1,3,4-thiadiazole moieties is may due to the presence of the $=\mathrm{N}-\mathrm{C}-\mathrm{S}$ moiety. Synthesis by either ferric chloride or acids catalyzed oxidative cyclization of thiosemicarbazide derivatives and biological studies of similar 5-[Aryl]-1, 3, 4-thiadiazol-2-amines were reported ${ }^{29,}{ }^{30}$. However the detailed spectral characterization and DNA studies of the 5-[Aryl]-1, 3, 4-thiadiazol-2not reported so far. In consideration of diverse biological properties of these heterocyclic scaffolds and

* Corresponding author.

E-mail address: muralikp21@gmail.com (P M. Krishna)

(C) 2019 by the authors; licensee Growing Science, Canada

doi: $10.5267 /$ j.ccl.2019.004.004 
our continued interest on sulphur and nitrogen containing derivates ${ }^{31-37}$, prompted us to design and synthesize heterocyclic thiadiazole moieties and to study their DNA studies.<smiles>Cc1nnc(SCC2=C(C(=O)O)N3C(=O)C(NC(=O)Cn4cc(Cl)c(=O)c(Cl)c4)C3SC2)s1</smiles>

(a) Cefazolin Sodium<smiles>Cn1c([N+](=O)[O-])cnc1-c1nnc(N)s1</smiles>

(b) Megazol

Fig. 1. Biologically active 1,3,4-thiadiazole containing drugs

\section{Results and Discussion}

\subsection{Synthesis and Characterization}

As shown in Scheme 1, the 5-[substituted]-1, 3, 4-thiadiazol-2-amines (1-7) were prepared through the cyclization of thiosemicarbazones. The isolated compounds were obtained in good to excellent yield and are stable at room temperature, non-hygroscopic in nature and almost insoluble in water and readily soluble in common organic solvents like methanol, ethanol, DMSO and DMF. The analytical data of the prepared compounds are in good agreement with the proposed formulae of the ligands. The structural elucidation of the compounds were done by FT-IR, UV-Vis, ${ }^{1} \mathrm{H}-\mathrm{NMR},{ }^{13} \mathrm{C}-\mathrm{NMR}$ and LCMS spectroscopy techniques and data are compiled in the synthesis part.

IR spectra of the compounds were recorded in the $4000-400 \mathrm{~cm}^{-1}$ region using Bruker Alpha FT-IR spectrometer by $\mathrm{KBr}$ pellet method. The FT-IR spectra of compounds are shown in Figs. S1-S7. The stretching vibrational frequency of primary amine $(\mathrm{N}-\mathrm{H})$ was observed $3072-3400 \mathrm{~cm}^{-1}$. The sharp and moderately intense stretching vibrational bands between $2946-3040 \mathrm{~cm}^{-1}$ are assigned to aromatic C- $\mathrm{H}$ stretching. The most characteristic band, the $\mathrm{C}=\mathrm{N}$ stretching vibration pertaining to the thiadiazole ring is present $1590-1636 \mathrm{~cm}^{-1}$ in the range ${ }^{38}$, and stretching vibration for $\mathrm{C}-\mathrm{S}-\mathrm{C}$ of thiodiazole moiety observed in the range of 812-854 $\mathrm{cm}^{-1}$. In compounds 4-6, the $\mathrm{C}-\mathrm{X}$, where $\mathrm{X}=\mathrm{F}$ or $\mathrm{Cl}$ stretching vibration observed in the range of $681-687 \mathrm{~cm}^{-1}$.

The NMR spectra of all compounds were obtained using Agilen with ATB probe NMR spectrometer $\left(400 \mathrm{MHz}\right.$ for ${ }^{1} \mathrm{H}$ and $100 \mathrm{MHz}$ for ${ }^{13} \mathrm{C}$ ) at room temperature in DMSO- d6. In ${ }^{1} \mathrm{H}-\mathrm{NMR}$ spectra (Figs. S8-S14), the aromatic protons resonate at $6.7-7.5 \mathrm{ppm}$, and the thiadiazole amine protons appeared at 7.6-8.04 ppm. In ${ }^{13}$ C-NMR spectra (Figs. S15-S20), it is clearly indicate that the 1,3,4thiadiazole ring was formed on cyclization reaction by thiosemicarbazones were confirmed by observing $-\mathrm{C}=\mathrm{N}$ group between $148-169 \mathrm{ppm}$. The aromatic carbon atoms of the compounds resonate at $112-130 \mathrm{ppm}$ The LC-MS data were obtained by Agilent 1200 series LC-MicromasszQ spectrometer. In mass spectra (Figs. S21-S27), The molecular ion peak of the thiadiazole compounds matching with the calculated values. 


\subsection{DNA binding studies}

\subsubsection{DNA-Binding Studies by Electronic absorption spectral studies}

The electronic spectroscopy is most useful technique, which is commonly used for study DNA binding interaction with small molecules ${ }^{39}$. Generally, when molecules bind to DNA with strong interaction such as intercalation, the intensity of absorption decreases and red shift is observed. If a ligand binds through non-intercalative or electrostatically with DNA, may result in either hyperchromism or hypochromism ${ }^{40}$. The DNA binding efficiency of prepared compounds (except 1 and 7) was monitored by comparing the their absorption spectra with and without CT-DNA. The absorption titrations of compounds carried out at fixed concentration of thiadiazole compound (1.36$6.65 \mathrm{mM})$ with varying DNA concentrations $\left(25-350 \mu \mathrm{L}\right.$ of $2.273 \times 10^{-6} \mathrm{molL}^{-1}$ solutions of stock CTDNA) under physiological conditions of $\mathrm{pH}$ 7.01. The resultant spectral graphs are given in Fig. $\mathbf{2}$ and Figs. S28-S31.

Table 1. Electronic absorption spectral data with addition of CT-DNA to compounds, 1-7

\begin{tabular}{|c|c|c|c|c|c|c|}
\hline \multirow[b]{2}{*}{ Compound } & \multicolumn{2}{|c|}{$\lambda_{\text {max }}(\mathrm{nm})$} & \multirow{2}{*}{$\begin{array}{l}\Delta \lambda_{\max } \\
(\mathrm{nm})\end{array}$} & \multirow[t]{2}{*}{$\% \mathrm{H}$} & \multirow[b]{2}{*}{$\mathrm{K}_{\mathrm{b}}\left(\mathrm{M}^{-1}\right)$} & \multirow[b]{2}{*}{$\Delta \mathrm{G}(\mathrm{kJ} / \mathrm{mol})$} \\
\hline & Free & Bound & & & & \\
\hline 1 & - & - & - & - & - & - \\
\hline 2 & 240 & 240 & 0 & 2.69 & $2.072 \times 10^{7}$ & -41.746 \\
\hline 3 & 241 & 241 & 0 & 4.91 & $3.792 \times 10^{7}$ & -43.244 \\
\hline 4 & 238 & 239 & 1 & -0.82 & $1.408 \times 10^{7}$ & -40.788 \\
\hline 5 & 300 & 303 & 3 & -1.05 & $3.397 \times 10^{7}$ & -42.971 \\
\hline 6 & 300 & 300 & 0 & 1.48 & $2.084 \times 10^{7}$ & -41.760 \\
\hline 7 & - & - & - & - & - & \\
\hline
\end{tabular}

The presence of Isosbestic point in the spectra indicates that no other species were present in the reaction except thiadiazole and DNA at equilibrium. In order to determine affinity of ligands with CTDNA quantitatively, the intrinsic binding constant $\mathrm{K}_{\mathrm{b}}$ for prepared compounds with CT-DNA was obtained by monitoring the changes in absorbance between $240-350 \mathrm{~nm}$, which attributed due to $\pi \rightarrow \pi^{*}$ intra-ligand transition and $\mathrm{Kb}$ values were evaluated in $10^{7}$ order $\left(1.408 \times 10^{7}-3.792 \times 10^{7} \mathrm{M}^{-1}\right)$ of magnitude. With increase in concentration of DNA shows hyperchromism / hypochromism no/or negligible blue/red shiftindicate strong interaction of the compounds with CT DNA mainly through electrostatic or groove binding ${ }^{41}$. Based on the spectral change and $\mathrm{Kb}$ values compounds may be assigned as groove binders. The kinetics and thermodynamics of drug-DNA interaction in terms of binding constant $(\mathrm{Kb})$ and Gibbs free energy change $(\Delta \mathrm{G})$ were evaluated by using the classical Van't Hoff's equation, $\Delta \mathrm{G}=-2.303 \mathrm{RT} \log \mathrm{K} b$.
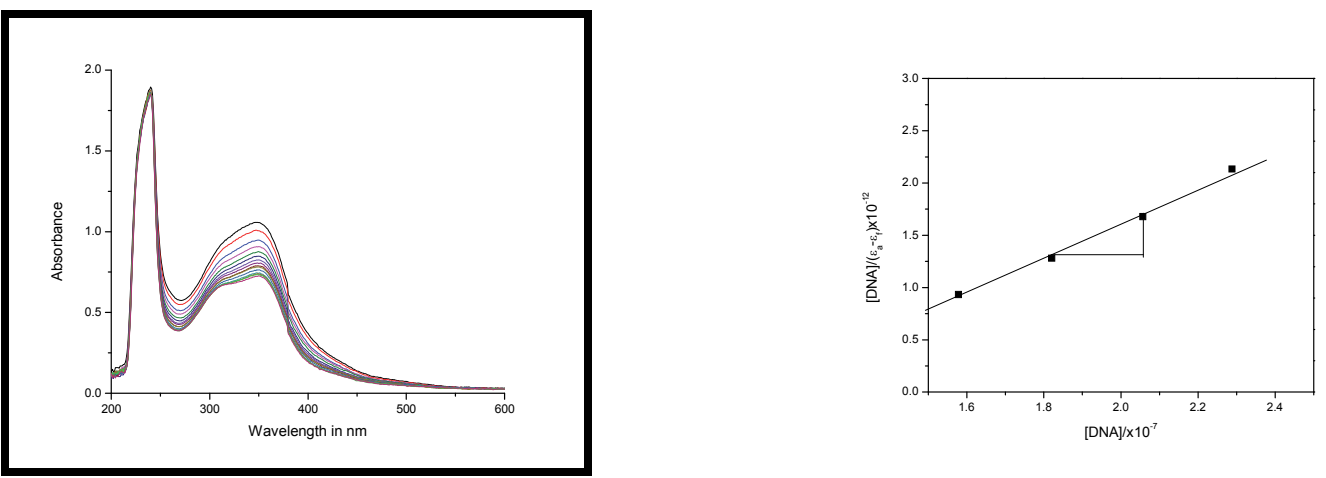

Fig. 2: The electronic absorption spectra of 2 in the absence and presence of increasing amounts of CTDNA. Arrow shows the change in the absorbance with increase the DNA concentration. Inset: plot of $[\mathrm{DNA}] /\left(\varepsilon_{\mathrm{a}}-\varepsilon_{\mathrm{f}}\right) \operatorname{Vs}[\mathrm{DNA}]$. 
The negative $\Delta \mathrm{G}$ values confirmed spontaneous binding of compounds with DNA via. formation of stable complexes, Table 2. In order to further investigate the binding mode, fluorescence analyses were performed.

\subsubsection{DNA-Binding Studies by Fluorescence Spectroscopy}

Under similar conditions as in absorption titrations, fluorescence studies were undertaken for further proof for the binding efficiency of the compounds with DNA.The quenching assay method based on the displacement of the intercalating dye, ethidium bromide (EB), from CT-DNA was employed to investigate the interaction mode between the thiadiazole and CT-DNA. EB is a very useful DNA structural probe, which shows a significant increase in fluorescence intensity when binding to the base pair of DNA through intercalating. However, the enhanced fluorescence can be quenched if there is a second complex that can replace the bound EB or break the secondary structure of DNA ${ }^{42-44}$. It has been reported that the groove DNA binders can also cause the decrease in EB emission intensities. The effects were, however, only moderate ${ }^{45}$

Table 2. Fluorimetric spectral data with addition of CT-DNA to compounds, 1-7

\begin{tabular}{cccccccc}
\hline Compound & $\mathrm{K}_{\mathrm{SV}} \times 10^{5}\left(\mathrm{M}^{-1}\right)$ & $\begin{array}{c}\mathrm{K}_{\mathrm{q}} \times 10^{13} \\
\left(\mathrm{M}^{-1} \mathrm{~S}^{-1}\right)\end{array}$ & $\mathrm{r}^{2}$ & $\mathrm{~K}_{\mathrm{b}}\left(\mathrm{M}^{-1}\right)$ & $\mathrm{n}$ & $\begin{array}{c}\mathrm{r}^{2} \\
(\mathrm{~kJ} / \mathrm{mol})\end{array}$ \\
\hline 1 & - & - & - & - & - & - & - \\
2 & 4.109 & 4.109 & 0.9905 & $2.6160 \times 10^{6}$ & 1.16 & 0.9993 & 36.618 \\
3 & 3.152 & 3.152 & 0.9873 & $3.8584 \times 10^{6}$ & 1.22 & 0.9968 & 37.581 \\
4 & 4.172 & 4.172 & 0.9952 & $2.1486 \times 10^{6}$ & 1.14 & 0.9991 & 36.130 \\
5 & 7.498 & 7.498 & 0.9972 & $2.4620 \times 10^{7}$ & 1.30 & 0.9946 & 42.173 \\
6 & 6.014 & 6.014 & 0.9890 & - & 1.98 & 0.9899 & - \\
7 & - & - & - & - & - & - & - \\
\hline
\end{tabular}

The fluorescence quenching of DNA-bound EB can be described by the linear Stern-Volmer equation ${ }^{46}$ in which the synthesized compounds were the quenchers:

$$
\frac{F_{0}}{F}=1+k_{\mathrm{q}} \tau_{0}[Q]=1+K_{\mathrm{SV}}[Q]
$$

$\mathrm{F}_{0}$ and $\mathrm{F}$ represent the fluorescence intensities in the absence and presence of quencher, respectively; $\mathrm{K}_{\mathrm{Sv}}$ is a linear Stern-Volmer quenching constant; [Q] is the concentration of quencher and $\tau_{0}$ is the average fluorescence lifetime of the quencher $\left(10^{-8} \mathrm{~s}\right)$. A plot of $\mathrm{F}_{0} / \mathrm{F}$ versus [Q] gave a slope to intercept which is equal to $\mathrm{K}_{\mathrm{Sv}}$. The $\mathrm{K}_{\mathrm{Sv}}$ values for the tested compounds are given in Table 2. From $\mathrm{K}_{\mathrm{Sv}}$ values, compound 5 had the highestK $\mathrm{Sv}$ value, which suggested that compound bound most strongly to CTDNA. Then, a linear Stern-Volmer plot (Fig. 3 and S32-35) indicates either one type of binding or quenching process is occurring by static or dynamic mechanism ${ }^{47}$.

Further, to differentiate between the quenching processes, the bimolecular quenching rate constant, $\mathrm{K}_{\mathrm{q}}$ is calculated. The $\mathrm{K}_{\mathrm{q}}$ value for static quenching mechanism has been reported $\left(10^{10} \mathrm{Ms}\right)$. The calculated $\mathrm{K}_{\mathrm{q}}$ values (Table 2) at $298 \mathrm{~K}$ were found greater than the expected values, which indicate the quenching process is static rather than dynamic ${ }^{48}$.

It is also calculated the intrinsic binding constant $(\mathrm{Kb})$ and size of binding sites (n) compounds from the intercept and slope of plot $\log \left(\mathrm{F}_{0}-\mathrm{F} / \mathrm{F}\right)$ versus $\log [\mathrm{Q}]$, respectively using the following equation $^{49}$.

$$
\log \frac{F-F_{0}}{F}=\log K_{b}+n \log [D N A]
$$

The evaluated data of $\mathrm{Kb}$ and $\mathrm{n}$ values complemented the results obtained from obtained using absorption spectroscopy. From the values of $n, n>1$ showed the possibility of more available sites; 
hence the interactions may occur along with intercalation.

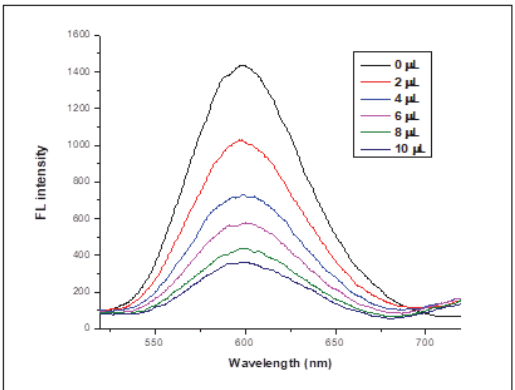

(a)

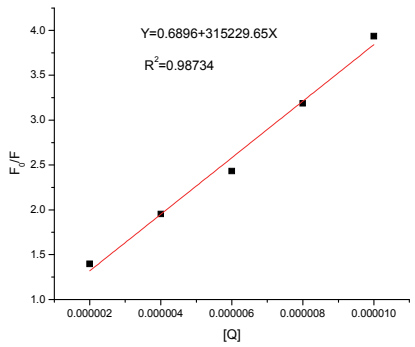

(b)

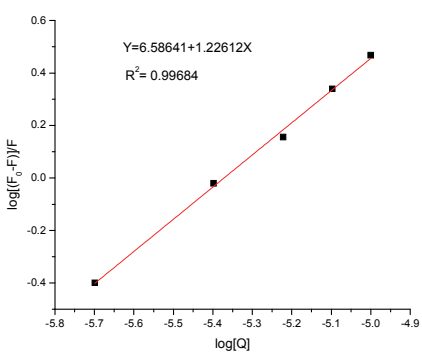

(c)

Fig. 3. (a) Fluorescence titration of CT-DNA and EB (intercalator) complex with compound $3(0-10$ $\mu \mathrm{L}$ ) (b) Stern-Volmer plot for fluorescence quenching of compound 3 by EB in absence and presence of CT-DNA (c) Plot of $\log (\mathrm{F} 0-\mathrm{F}) / \mathrm{F}$ as a function of $\log [\mathrm{Q}]$.

Using binding constant values $\Delta \mathrm{G}$ were calculated and given in Table 2 and values are comparable with that obtained from absorption titration method. Based on fluorescence change it is possible to bind the CT-DNA and thiadiazole moieties in groove binding mode.

\subsection{DNA cleavage studies}

The DNA Cleavage studies of the prepared compounds were studied using Gel electrophoresis technique, which is based on the migration of DNA under the influence of an electric potential. DNA cleavage was monitored by pUC18 DNA using tris-acetic acid-EDTA (TAE) buffer (pH 8.0). The samples were incubated for $1 \mathrm{~h}$ at $37{ }^{\circ} \mathrm{C}$. After incubation, $2 \mu \mathrm{L}$ of loading buffer $(0.25 \%$ bromophenol blue, $0.25 \%$ xylene cynol and $60 \%$ glycerol) was added to the reaction mixture and loaded onto a $1 \%$ agarose gel containing $1.0 \mu \mathrm{g} / \mathrm{mL}$ of ethidium bromide. The electrophoresis was carried out at $100 \mathrm{~V}$ in Tris-acetic acid- EDTA (TAE) buffer till the bromophenol blue reached 3/4th of the gel. Bands were visualized by using UV trans-illuminator and photographed. For comparison purposes, the cleavage reaction for compounds was carried out in the absence and presence of $\mathrm{H}_{2} \mathrm{O}_{2}$ and is shown in Fig. 4.

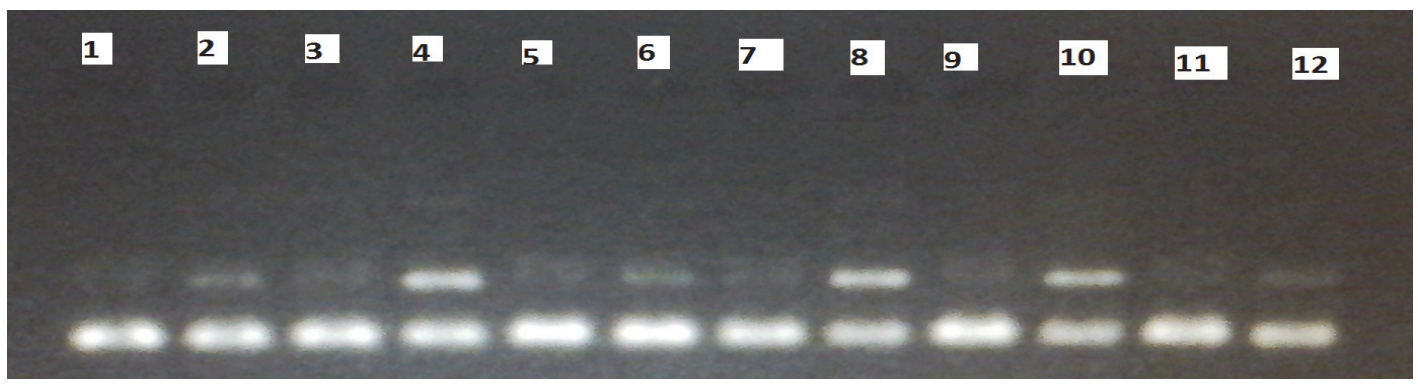

Fig. 4. Gel electrophoresis of compounds 2-6, Lane 1: Control DNA, Lane 2: Control $\mathrm{DNA}+\mathrm{H}_{2} \mathrm{O}_{2}$. Lane 3 : $100 \mu \mathrm{M}$ of $2+\mathrm{DNA}+$ buffer, Lane $4: 100 \mu \mathrm{M}$ of $2+\mathrm{DNA}+$ buffer $+\mathrm{H}_{2} \mathrm{O}_{2}$, Lane $5: 100 \mu \mathrm{M}$ of $3+\mathrm{DNA}+$ buffer, Lane 6: $100 \mu \mathrm{M}$ of $3+$ DNA + buffer $+\mathrm{H}_{2} \mathrm{O}_{2}$, Lane 7: $100 \mu \mathrm{M}$ of $4+\mathrm{DNA}+$ buffer, Lane 8: $100 \mu \mathrm{M}$ of 4+DNA+buffer $+\mathrm{H}_{2} \mathrm{O}_{2}$, Lane 9: $100 \mu \mathrm{M}$ of 5+DNA +buffer, Lane 10: $100 \mu \mathrm{M}$ of 5+DNA+buffer $+\mathrm{H}_{2} \mathrm{O}_{2}$, Lane 11: $100 \mu \mathrm{M}$ of $\mathbf{6}+\mathrm{DNA}+$ buffer, Lane $12: 100 \mu \mathrm{M}$ of $\mathbf{6}+\mathrm{DNA}+$ buffer $+\mathrm{H}_{2} \mathrm{O}_{2}$.

The ability of DNA cleavage was determining based on the capacity of thiadiazole moieties in conversion of open circular (OC) or nicked circular (NC) nucleic acid from its super coiled (SC) structure. 
From Fig. 4 it observed that the does show any cleavage activity in the absence $\mathrm{H}_{2} \mathrm{O}_{2}$ but in the presence of $\mathrm{H}_{2} \mathrm{O}_{2}$ the activity enhanced moderately. The results indicated that the role of thiadiazole moiety in isolated DNA cleavage reaction. The thiadiazole molecules were able to convert supercoiled DNA into open circular DNA and the results indicate that the process of DNA cleavage may be closely related to the oxidative type of cleavage.

\section{Conclusion}

This paper describes the synthesis and characterization of thiadiazoles. The spectral data showed that the formation of compounds. The DNA binding studies reveals that, the molecules are avid binders to CT-DNA. The DNA cleavage studies indicate that the process of DNA cleavage may be closely related to the oxidative type of cleavage.

The prepared compounds might be important biologically, and their medical research applications should be investigated.

\section{Acknowledgements}

The authors thank to Department of Chemistry and Physics for providing lab facilities. NS is thankful to the department of OBC Government of Karnataka for doctoral Scholarship award.

\section{Experimental methods}

\subsection{Materials and methods}

All the starting materials, Calf thymus DNA was obtained from sigma Aldrich and PUC ${ }^{18}$ DNA obtained from Genie, Bangalore. Melting points of the compounds were measured by open capillary method; ${ }^{1} \mathrm{H}-\mathrm{NMR}$ and ${ }^{13} \mathrm{C}$ NMR spectra were recorded on Agilent at $400 \mathrm{MHz}$ and $100 \mathrm{MHz}$ in $\mathrm{d}_{6-}$ DMSO solvent. FT-IR was recorded using Bruker alpha KBR pellet method with silicon carbide as IR source; LC-MS was obtained on Agilent 1200 series LC \& Micromass Q spectrometer. Fluorescence emission spectra were recorded using a F-2300 Spectrofluorimeter (Hitachi, Japan) equipped with 1.0 $\mathrm{cm}$ quartz cell at $298 \mathrm{~K}$ ). The excitation and emission slit widths were maintained at $5.0 \mathrm{~nm}$, and the excitation wavelength $\left(\mathrm{k}_{\mathrm{ex}}\right)$ was fixed to $500 \mathrm{~nm}$ in the range $520-700 \mathrm{~nm}$ for ethidium bromide and by excitation at $350 \mathrm{~nm}$ in the range 390-600 $\mathrm{nm}$ for thidiazoles. Absorption titrations were carried on Elico SL 159 UV-visible spectrophotometer in 200-500 $\mathrm{nm}$ range equipped with $1.0 \mathrm{~cm}$ quartz cell at room temperature.

\subsection{Synthesis of substituted thiadiazoles}

All the titled compounds were prepared as shown below.

\subsubsection{Synthesis of thiosemicarbazones}

The starting precursors, thiosemicarbazones were prepared according to procedure described in literature $^{50}$. An equimolar quantity of a warm alcoholic solution of aldehyde and $5 \%$ glacial acetic acid aqueous solution of thiosemicarbazide were mixed and refluxed for 2 hours. The reaction mixer cooled to room temperature. Then, the product was separated was collected by filtration and recrystallized in alcohol.

\subsubsection{Synthesis of thiadiazoles}

The thiadiazoles (1-7) were prepared (Scheme 1) according the procedure described in literature ${ }^{8}$, ${ }^{29,30}$.To a suspended aqueous solution of thiosemicarbazone $(0.05 \mathrm{~mol})$ warm aquoues solution of ferric 
chloride $(0.015 \mathrm{~mol})$ was addedslowly with constant stirring, then contents were refluxed at $80-90^{\circ} \mathrm{C}$ for $45 \mathrm{~min}$. The resultant solution was filtered and added citric acid $(0.11 \mathrm{~mol})$ and sodium citrate $(0.05 \mathrm{~mol})$. The obtained mixture was divided in to 4 parts and each part on neutralized with $10 \%$ ammonia solution the formed amine was filtered, dried and recrystallized with alcohol.

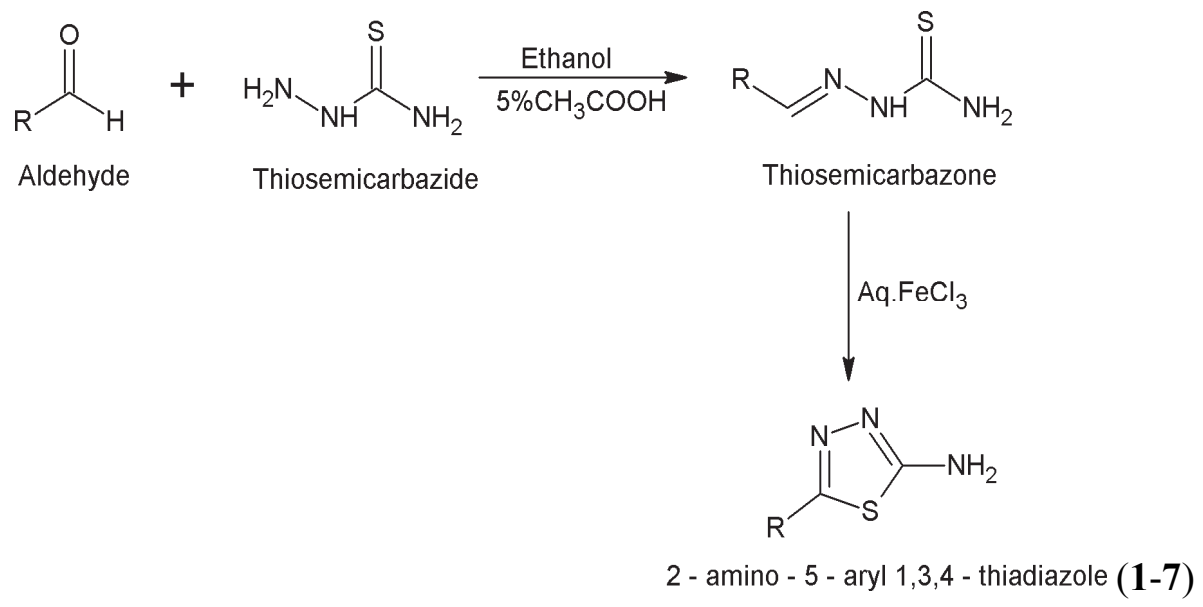

where $\mathrm{R}=4$-Isopropylbenzaldehyde (1), 4-Dimethylaminobenzaldehyde (2)

Vertraldehyde or 3,4-Dimethoxybenzaldehyde (3), 4-Fluoro benzaldehyde (4),

4-Chloro benzaldehyde (5), 4-Chloro-1-methyl-pyrazole carboxaldehyde (6),

3-Nitro benzaldehyde (7)

\subsection{Spectral data}

Scheme1:Synthesis of 2-amino-5-substituted thiadiazoles

\subsubsection{5-[4- (Propan-2yl)phenyl]-1,3,4-thiadiazol-2-amine (1)}

MP $\left({ }^{0} \mathrm{c}\right): 172-176, \mathrm{IR}\left(\mathrm{cm}^{-1}\right): 3090-3277\left(\mathrm{NH}_{2}\right), 1626(\mathrm{C}=\mathrm{N}), 1509(\mathrm{C}=\mathrm{Car}), 2957(-\mathrm{CH}$ aromatic $), 823(\mathrm{C}-$ S-Cstr); ${ }^{1} \mathrm{H}$ NMR: 1.16-1.21(d, $\left.6 \mathrm{H}\right), \quad 7.63(\mathrm{~d}, \quad 2 \mathrm{H}, \mathrm{J}=7.6 \mathrm{~Hz}$, aromatic $), 7.30(\mathrm{~d}, \quad 2 \mathrm{H}, \mathrm{J}=7.6 \mathrm{~Hz}$, aromatic), 7.33(2H(s) $\left.\mathrm{NH}_{2}\right), 2.87(\mathrm{~m}, 1 \mathrm{H},-\mathrm{CH}) ;{ }^{13} \mathrm{C} \mathrm{NMR}: 24 \mathrm{ppm}, 33 \mathrm{ppm}, 126 \mathrm{ppm}, 127 \mathrm{ppm}, 128 \mathrm{ppm}$, 129ppm, 150ppm, 156ppm \& 168ppm; LCMS(m/z) for $\mathrm{C}_{11} \mathrm{H}_{13} \mathrm{~N}_{3} \mathrm{~S}: 219.299$, Found: 220.05 .

\subsubsection{5-[4-(Dimethylamino)phenyl]-1,3,4-thiadiazol-2-amine (2)}

MP $\left({ }^{0} \mathrm{c}\right): 135-140$, IR $\left(\mathrm{cm}^{-1}\right): 3143-3248\left(\mathrm{NH}_{2}\right), 2946(-\mathrm{CH}$ aromatic $), 2893(-\mathrm{CH}), 1597(\mathrm{C}=\mathrm{N})$, $1509(\mathrm{C}=\mathrm{C}), 812(\mathrm{C}-\mathrm{S}-\mathrm{C}) ;{ }^{1} \mathrm{H}-\mathrm{NMR}: 2.7-2.9(\mathrm{~m}, 6 \mathrm{H}), 6.7-7.08(\mathrm{~m}, 4 \mathrm{H}$, aromatic $)$, 7.6-7.7(d, 2H, $\left.\mathrm{NH}_{2}\right)$; ${ }^{13} \mathrm{C}-\mathrm{NMR}: 43 \mathrm{ppm}, 111 \mathrm{ppm}, 112 \mathrm{ppm}, 127 \mathrm{ppm}, 127 \mathrm{ppm}, 129 \mathrm{ppm}, 130 \mathrm{ppm}, \& 131 \mathrm{ppm}$; LCMS(m/z) for $\mathrm{C}_{10} \mathrm{H}_{12} \mathrm{~N}_{4} \mathrm{~S}: 220.288$, Found: 221.10.

\subsubsection{5-(3,4-dimethoxyphenyl)-1,3,4-thiadazol-2-amine(3)}

MP $\left({ }^{0} \mathrm{c}\right): 148-152, \operatorname{IR}\left(\mathrm{cm}^{-1}\right): 3253-3346\left(\mathrm{NH}_{2}\right), 3040(-\mathrm{CH}$ aromatic $), 2954-2823(-\mathrm{CH}), 1614(\mathrm{C}=\mathrm{N})$, 1504 $(\mathrm{C}=\mathrm{N}), 854(\mathrm{C}-\mathrm{S}-\mathrm{C})$; ${ }^{1} \mathrm{H}-\mathrm{NMR}: 3.74(\mathrm{~s}, 6 \mathrm{H}$, dimethoxy), 6.9-7.1 (m, 3H, aromatic), 7.26(s, 2H, $\left.\mathrm{NH}_{2}\right) ;{ }^{13} \mathrm{C}-\mathrm{NMR}$ : 55ppm, 56ppm, 109ppm, 112ppm, 120ppm, 124ppm, 149ppm, 150ppm, 156ppm \& 168ppm, LCMS(m/z) for $\mathrm{C}_{10} \mathrm{H}_{11} \mathrm{~N}_{3} \mathrm{O}_{2} \mathrm{~S}: 237.273$, Found: 238 .

\subsubsection{5-(4-Fluorophenyl)-1,3,4-thiadiazol-2-amine(4)}


MP ( $\left.{ }^{0} \mathrm{c}\right): 214-218$, IR $\left(\mathrm{cm}^{-1}\right): 3000-3400\left(\mathrm{NH}_{2}\right), 2976(-\mathrm{CH}$ aromatic $), 1590(\mathrm{C}=\mathrm{N}), 1506(\mathrm{C}=\mathrm{C})$, 1000(C=F), 829(C-S-C); ${ }^{1} \mathrm{H}-\mathrm{NMR}$ : 7.26-7.36(d, 4H, aromatic), 7.57(s, 2H, $\left.\mathrm{NH}_{2}\right) ;{ }^{13} \mathrm{C}-\mathrm{NMR}$ : 116ppm, $128 \mathrm{ppm}, 155 \mathrm{ppm}, 161 \mathrm{ppm}, 164 \mathrm{ppm}, \& 169 \mathrm{ppm}, \mathrm{LCMS}(\mathrm{m} / \mathrm{z})$ for $\mathrm{C}_{8} \mathrm{H}_{6} \mathrm{~N}_{3} \mathrm{SF}: 195.213$, Found: 196.05 . 4.3.5. 5-(4-Chlorophenyl)-1,3,4-thiadiazol-2-amine(5)

MP ( $\left.{ }^{0} \mathrm{c}\right):$ 206-210, IR $\left(\mathrm{cm}^{-1}\right): 3072-3243\left(\mathrm{NH}_{2}\right), 1591(\mathrm{C}=\mathrm{N}), 1508(\mathrm{C}=\mathrm{Car}), 829(\mathrm{C}-\mathrm{S}-\mathrm{Cstr}), 681(\mathrm{C}-\mathrm{Cl})$; ${ }^{1} \mathrm{H}$ NMR: $7.75(\mathrm{~d}, 2 \mathrm{H}$,aromatic, $\mathrm{J}=8 \mathrm{~Hz}), 7.51(\mathrm{~d}, 2 \mathrm{H}$,aromatic, $\mathrm{J}=7.6 \mathrm{~Hz}), 7.45\left(\mathrm{~s}, 2 \mathrm{H}, \mathrm{NH}_{2}\right) \cdot{ }^{13} \mathrm{C}$ NMR: $128.3 \mathrm{ppm}, 129.6 \mathrm{ppm}, 130.3 \mathrm{ppm}, 134.4 \mathrm{ppm}, 155.6 \mathrm{ppm} \& 169.3 \mathrm{ppm} ; \mathrm{LCMS}(\mathrm{m} / \mathrm{z})$ for $\mathrm{C}_{8} \mathrm{H}_{6} \mathrm{~N}_{3} \mathrm{SCl}$ : 211.663, Found: 212.50.

\subsubsection{5-(4-Chloro-1-methyl-1H-pyrazol3-yl)-1,3,4-thiadiazol-2-amine(6)}

MP ( $\left.{ }^{0} \mathrm{c}\right): 265-270, \operatorname{IR}\left(\mathrm{cm}^{-1}\right): 3092-3256\left(\mathrm{NH}_{2}\right), 1636(\mathrm{C}=\mathrm{N}), 1498(\mathrm{C}=\mathrm{Car}), 2936(-\mathrm{CH}$ aromatic $), 829(\mathrm{C}-$ S-Cstr), 681(C-Cl); ${ }^{1} \mathrm{H}-\mathrm{NMR}: 3.82\left(\mathrm{~s}, 3 \mathrm{H}, \mathrm{CH}_{3}\right), 7.37(\mathrm{~s}, 1 \mathrm{H}$, aromatic), 8.04(s, 2H,NH$)$; ${ }^{13} \mathrm{C}-\mathrm{NMR}$ : 106ppm, 132ppm, 139ppm, 148ppm \&168ppm, LCMS(m/z) for $\mathrm{C}_{6} \mathrm{H}_{6} \mathrm{~N}_{5} \mathrm{SCl}$ : 215.657, Found 216.

\subsubsection{5-(3-Nitrophenyl)-1,3,4-thiadiazol-2-amine (7)}

MP $\left({ }^{0} \mathrm{c}\right):$ 206-208,IR $\left(\mathrm{cm}^{-1}\right): 3137-3268\left(\mathrm{NH}_{2}\right), 1622(\mathrm{C}=\mathrm{N}), 1470(\mathrm{C}=\mathrm{Cstr}), 774(\mathrm{C}-\mathrm{S}) ;{ }^{1} \mathrm{H}$ NMR: 8.293 $\left(\mathrm{s}, 1 \mathrm{H} \mathrm{NH} \mathrm{N}_{2}\right), 8.06(\mathrm{~d}, 1 \mathrm{H}, 7.2 \mathrm{~Hz}) ; 7,95 .(\mathrm{d}, 1 \mathrm{H}, 7.2 \mathrm{~Hz}) 7.58(1 \mathrm{H}(\mathrm{t}), 8 \mathrm{~Hz}, 7.6 \mathrm{~Hz}) ;{ }^{13} \mathrm{C}$ NMR: $120.4 \mathrm{ppm}$, 124.2 ppm, 131.3 ppm, 132.8 ppm, 132.9 ppm, 148.6 ppm, 154.5 ppm \&169.8 ppm; LCMS (m/z) Caculated for $\mathrm{C}_{8} \mathrm{H}_{6} \mathrm{~N}_{4} \mathrm{O}_{2} \mathrm{~S}: 222.22$ Found 223 .

\subsection{DNA binding studies}

\subsubsection{DNA studies by absorption titrations}

The electronic spectroscopy is commonly used technique to study the DNA binding activity studies. A solution of CT-DNA in $50 \mathrm{mM}$ Tris- $\mathrm{HCl} / 50 \mathrm{mM} \mathrm{NaCl}$ buffer solution was prepared at $\mathrm{pH}$ 6.9-7.01 gives a ratio of UV absorbance at 260 and $280 \mathrm{~nm}$ of 1.8-1.9 indicating that DNA was free of proteins ${ }^{51}$. Then a concentrated stock solution of DNA was prepared in $50 \mathrm{mM}$ Tris $\mathrm{HCl} / 50 \mathrm{mM} \mathrm{NaCl}$ in double distilled water at $\mathrm{pH}$ 6.9-7.01 and the concentration of CT-DNA was determined per nucleotide by taking the absorption coefficient $\left(6600 \mathrm{dm}^{3} \mathrm{~mol}^{-1} \mathrm{~cm}^{-1}\right)$ at $260 \mathrm{~nm}^{52}$ Stock solutions were stored at $4^{0} \mathrm{C}$ and were used after no more than 4 days. A $2 \mathrm{~mL}$ solution in $1 \mathrm{~cm}$ quartz containing fixed concentration of the compounds, except 1 and $\mathbf{5}(1.36-6.65 \mathrm{mM})$ was titrated by successive addition of $25 \mu 1$ to $350 \mu 1$ DNA whose stock CT-DNA concentration $2.273 \times 10^{-6} \mathrm{molL}^{-1}$. The spectra were recorded against blank solution containing same concentration of DNA. Then the intrinsic binding constant $\mathrm{K}_{\mathrm{b}}{ }^{53}$

$$
\frac{[\mathrm{DNA}]}{\left(\epsilon_{\mathrm{A}}-\epsilon_{\mathrm{B}}\right)}=\frac{[\mathrm{DNA}]}{\left(\epsilon_{\mathrm{B}}-\epsilon_{\mathrm{F}}\right)}+\frac{1}{\mathrm{~K}_{\mathrm{b}}\left(\epsilon_{\mathrm{B}}-\epsilon_{\mathrm{F}}\right)}
$$

where, $\epsilon_{A} \in_{B}$ and $\epsilon_{F}$ corresponds to the apparent, bound and free compound extinction coefficients, respectively. A plot of $\frac{[\mathrm{DNA}]}{\left(\epsilon_{\mathrm{A}}-\epsilon_{\mathrm{F}}\right)}$ versus [DNA] gave a slope of $\frac{1}{\left(\epsilon_{\mathrm{B}}-\epsilon_{\mathrm{F}}\right)}$ and Y-intercept equal to $\frac{1}{\mathrm{~K}_{\mathrm{b}}\left(\epsilon_{\mathrm{B}}-\epsilon_{\mathrm{F}}\right)}$, Hence $\mathrm{K}_{\mathrm{b}}$ was obtained from the ratio of the intercept to the slope ${ }^{37}$. The percentage of hyperchromicity or hypochrocicity for the CT-DNA/[Ligand] was obtained from $\left(\varepsilon_{\mathrm{a}}-\varepsilon \mathrm{f}\right) / \varepsilon \mathrm{f} \times 100$.

\subsubsection{DNA studies by Fluorescence Studies}

Ethidium bromide, cationic dye, which interacts strongly and specifically with DNA, is widely used in spectrofluorimetric studies due to increase in fluorescence upon binding that indicates intercalation of dye with DNA. Hence ethidium bromide-DNA complex quenching technique becomes a routine to 
compare the DNA binding mode of the prepared compounds. The fluorescence spectra of the compounds were recorded by using the excitation wavelength of $510 \mathrm{~nm}$, the emission wavelength was around $600 \mathrm{~nm}$. Before measurements, the mixture was mixed well. In the ethidium bromide (EB) fluorescence displacement experiment, $10 \mu \mathrm{L}$ of the EB Tris solution $(50 \mu \mathrm{M})$ was added to $10 \mu \mathrm{L}$ of DNA solution $(10 \mu \mathrm{L} \text { at saturated binding level })^{52}$. The compound was then titrated into the EB/DNA mixture. Before measurements, the solution was well mixed at room temperature for 5 min. Fluorescence spectra of EB bound to DNA were obtained at an excitation wavelength of $540 \mathrm{~nm}$ and an emission wavelength of $592 \mathrm{~nm}$.

\subsection{DNA cleavagestudies}

The DNA Cleavage studies of the prepared compounds were studied using Gel electrophoresis technique, which is based on the migration of DNA under the influence of an electric potential. DNA cleavage was monitored by pUC18 DNA using tris-acetic acid-EDTA (TAE) buffer ( $\mathrm{pH} 8.0$ ). The samples were incubated for $1 \mathrm{~h}$ at $37{ }^{\circ} \mathrm{C}$. After incubation, $2 \mu \mathrm{L}$ of loading buffer $(0.25 \%$ bromophenol blue, $0.25 \%$ xylene cynol and $60 \%$ glycerol) was added to the reaction mixture and loaded onto a $1 \%$ agarose gel containing $1.0 \mu \mathrm{g} / \mathrm{mL}$ of ethidium bromide. The electrophoresis was carried out at $100 \mathrm{~V}$ in Tris-acetic acid- EDTA (TAE) buffer till the bromophenol blue reached 3/4th of the gel. Bands were visualized by using UV transilluminator and photographed. For comparison purposes, the cleavage reaction for compounds was carried out in the absence and presence of $\mathrm{H}_{2} \mathrm{O}_{2}$. The ability of DNA cleavage was determining based on the capacity of thiadiazole moieties in conversion of open circular (OC) or nicked circular (NC) nucleic acid from its super coiled (SC) structure.

\section{Conflicts of Interest}

The authors declare that there is no conflict of interests regarding the publication of this paper.

\section{References}

1. Paul, A., \& Bhattacharya, S. (2012). Chemistry and biology of DNA-binding small molecules. Curr. Sci. (Bangalore), 102(2), 212-231.

2. KR, S. G., Mathew, B. B., Sudhamani, C. N., \& Naik, H. B. (2014). Mechanism of DNA binding and cleavage. Biomed., 2(1), 1-9.

3. Sastry, K. V., Routhu, S. R., Datta, S. G., Nagesh, N., Babu, B. N., Nanubolu, J. B., ... \& Kamal, A. (2016). Synthesis, DNA binding affinity and anticancer activity of novel 4 H-benzo $[\mathrm{g}][1,2,3]$ triazolo [5, 1-c][1, 4] oxazocines. Org. \& Biomol. Chem., 14(39), 9294-9305.

4. Lamani, D. S., Venugopala Reddy, K. R., Bhojya Naik, H. S., Savyasachi, A., \& Naik, H. R. (2008). Synthesis and DNA binding studies of novel heterocyclic substituted quinoline schiff bases: a potent antimicrobial agent. Nucleosides Nucleotides Nucleic Acids., 27(10-11), 11971210 .

5. Martinez, A., Alonso, D., Castro, A., Arán, V. J., Cardelús, I., Baños, J. E., \& Badia, A. (1999). Synthesis and Potential Muscarinic Receptor Binding and Antioxidant Properties of 3(Thiadiazolyl) pyridine 1-Oxide Compounds. Archiv der Pharmazie: Arch. Pharm. Pharm. Med. Chem, 332(6), 191-194.

6. Dai, H., Li, G., Chen, J., Shi, Y., Ge, S., Fan, C., \& He, H. (2016). Synthesis and biological activities of novel 1, 3, 4-thiadiazole-containing pyrazole oxime derivatives. Bioorganic Med. Chem. Lett., 26(15), 3818-3821.

7. Demirbas, A., Sahin, D., Demirbas, N., \& Karaoglu, S. A. (2009). Synthesis of some new 1, 3, 4thiadiazol-2-ylmethyl-1, 2, 4-triazole derivatives and investigation of their antimicrobial activities. Eur. J Med. Chem., 44(7), 2896-2903. 
8. Hu, Y., Li, C. Y., Wang, X. M., Yang, Y. H., \& Zhu, H. L. (2014). 1, 3, 4-Thiadiazole: synthesis, reactions, and applications in medicinal, agricultural, and materials chemistry. Chem. Rev., 114(10), 5572-5610.

9. Luo, Y. P., \& Yang, G. F. (2007). Discovery of a new insecticide lead by optimizing a targetdiverse scaffold: tetrazolinone derivatives. Bioorg. Med. Chem., 15(4), 1716-1724.

10. Chen, H., Li, Z., \& Han, Y. (2000). Synthesis and Fungicidal Activity against Rhizoctonia s olani of 2-Alkyl (Alkylthio)-5-pyrazolyl-1, 3, 4-oxadiazoles (Thiadiazoles).J. Agric. Food Chem., 48(11), 5312-5315.

11. Zheng, Q., Mi, N., Fan, Z., Zuo, X., Zhang, H., Wang, H., \& Yang, Z. (2010). 5-Methyl-1, 2, 3thiadiazoles synthesized via Ugi reaction and their fungicidal and antiviral activities. J. Agri. Food Chem., 58(13), 7846-7855.

12. Li, Z. S., Wang, W. M., Lu, W., Niu, C. W., Li, Y. H., Li, Z. M., \& Wang, J. G. (2013). Synthesis and biological evaluation of nonsymmetrical aromatic disulfides as novel inhibitors of acetohydroxyacid synthase. Bioorg. Med. Chem. Lett., 23(13), 3723-3727.

13. Tripathy, R., Ghose, A., Singh, J., Bacon, E. R., Angeles, T. S., Yang, S. X., ... \& Mallamo, J. P. (2007). 1，2，3-Thiadiazole substituted pyrazolones as potent KDR/VEGFR-2 kinase inhibitors. Bioorg. Med. Chem. Lett., 17(6), 1793-1798.

14. Polkam, N., Rayam, P., Anireddy, J. S., Yennam, S., Anantaraju, H. S., Dharmarajan, S., ... \& Balasubramanian, S. (2015). Synthesis, in vitro anticancer and antimycobacterial evaluation of new 5-(2, 5-dimethoxyphenyl)-1, 3, 4-thiadiazole-2-amino derivatives. Bioorg. Med. Chem. Lett., 25(7), 1398-1402.

15. Yadagiri, B., Gurrala, S., Bantu, R., Nagarapu, L., Polepalli, S., Srujana, G., \& Jain, N. (2015). Synthesis and evaluation of benzosuberone embedded with 1, 3, 4-oxadiazole, 1, 3, 4-thiadiazole and 1, 2, 4-triazole moieties as new potential anti proliferative agents. Bioorg. Med. Chem. Lett., 25(10), 2220-2224.

16. Jakovljević, K., Matić, I. Z., Stanojković, T., Krivokuća, A., Marković, V., Joksović, M. D., ... \& Joksović, L. (2017). Synthesis, antioxidant and antiproliferative activities of 1, 3, 4-thiadiazoles derived from phenolic acids. Bioorg. Med. Chem. Lett., 27(16), 3709-3715.

17. Gan, X., Hu, D., Chen, Z., Wang, Y., \& Song, B. (2017). Synthesis and antiviral evaluation of novel 1, 3, 4-oxadiazole/thiadiazole-chalcone conjugates. Bioorg. Med. Chem. Lett., 27(18), 42984301.

18. Skrzypek, A., Matysiak, J., Niewiadomy, A., Bajda, M., \& Szymański, P. (2013). Synthesis and biological evaluation of 1, 3, 4-thiadiazole analogues as novel AChE and BuChE inhibitors. Eur. J. Med. Chem., 62, 311-319.

19. McGleenon, B. M., Dynan, K. B., \& Passmore, A. P. (1999). Acetylcholinesterase inhibitors in Alzheimer's disease. Br. J. Clin. Pharm., 48(4), 471.

20. Wang, J., Zhang, H. Y., \& Tang, X. C. (2009). Cholinergic deficiency involved in vascular dementia: possible mechanism and strategy of treatment. Acta Pharmacol. Sin., 30(7), 879.

21. Reddy, K. R., Mamatha, R., Babu, M. S., Shiva Kumar, K., Jayaveera, K. N., \& Narayanaswamy, G. (2014). Synthesis and antimicrobial activities of some triazole, thiadiazole, and oxadiazole substituted coumarins. J. Heterocycl. Chem., 51(1), 132-137.

22. Wang, G., Jin, L., Ye, J., \& Li, X. (2010). Electrical and electrochemical properties of poly (2, 5dimercapto-1, 3, 4-thiadiazole)-polyaniline adduct intercalated graphite oxide composites. Mater. Chem. Phy., 122(1), 224-229.

23. Selvarasu, C., \& Kannan, P. (2015). Bent Shaped 1, 3, 4-Oxadiazole/Thiadiazole heterocyclic rings containing liquid crystals. J. Chem. Sci., 127(10), 1831-1838.

24. Kuo, H. M., Li, S. Y., Sheu, H. S., \& Lai, C. K. (2012). Symmetrical mesogenic 2, 5-bis (6naphthalen-2-yl)-1, 3, 4-thiadiazoles. Tetrahedron, 68(36), 7331-7337.

25. Prajapati, A. K., \& Modi, V. (2010). Bent-shaped mesogenic oxadiazole and thiadiazole derivatives from rod-shaped mesogenic hydrazide containing polar chloro group. Liq. Cryst., 37(4), 407-415.

26. Tomi, I. H. R., Al-Heetimi, D. T., \& Jaffer, H. J. (2017). Asymmetric 1, 3, 4-thiadiazole 
derivatives: synthesis, characterization and studying their liquid crystalline properties. $J$. Mol. Stru., 1141, 176-185.

27. Solmaz, R., Kardaş, G., Yazıcı, B., \& Erbil, M. (2008). Adsorption and corrosion inhibitive properties of 2-amino-5-mercapto-1, 3, 4-thiadiazole on mild steel in hydrochloric acid media. Colloids and Surf., 312(1), 7-17.

28. Maradiya, H. R. (2002). Monoazo disperse dyes based on 2-amino-1, 3, 4-thiadiazole derivatives. J. Serb. Chem. Soc., 67(11), 709-718.

29. Gowramma, B., Kulkarni, A., Gomathy, S., \& Kandula, R. (2012). Synthesis And Anticonvul sant Screening Of Some Novel 1, 3, 4-Thiadiazole Derivatives. J. Pharma. Res., 5(1), 58-60.

30. Gupta, A., Singh, P., Kamble, B., Kulkarni, A., \& Joghee Nanjan Chandrasekar, M. (2012). Synthesis, Docking and Biological Evaluation of Some Novel 5-bromo-2-(5-aryl-1, 3, 4thiadiazol-2-yl) isoindoline-1, 3-dione Derivatives Targeting ATP-binding Site of Topoisomerase II. Lett. Drug Design \& Discovery, 9(7), 668-675.

31. Sennappan, M., Krishna, P. M., Hosamani, A. A., \& Krishna, R. H. (2018). Synthesis, characterization, nucleic acid interactions and photoluminescent properties of methaniminium hydrazone Schiff base and its Mn (II), Co (II), Ni (II), Cu (II), Zn (II) and Cd (II) complexes. J. Mol. Stru., 1164, 271-279.

32. Reddy, N. G., Krishna, P. M., Kumar, S. S., Patil, Y. P., \& Nethaji, M. (2017). Structure and spectroscopic investigations of a bi-dentate $\mathrm{N}^{\prime}$-[(4-ethylphenyl) methylidene]-4hydroxybenzohydrazide and its $\mathrm{Co}$ (II), $\mathrm{Ni}$ (II), $\mathrm{Cu}$ (II) and $\mathrm{Cd}$ (II) complexes: Insights relevant to biological properties. J. Mol. Stru., 1137, 543-552.

33. Krishna, P. M., \& Reddy, K. H. (2016). Synthesis, structural characterization and DNA studies of nickel (II) complexes of (2E)-4N-substituted-2-[4-(propan-2-yl) Benzyli dene] Hydrazinecarbothioamide Schiff's bases. J. Chem. Pharmaceut. Res., 8(10), 61-68.

34. Gopal Reddy, N.P., Murali Krishna, P. Kottam, N. (2015). Novel metaleorganic photocatalysts: synthesis, characterization and decomposition of organic dyes, Spectrochim. Acta A, 137:371-377.

35. Murali Krishna, P., Anil Kumar, G.N., Hussain Reddy, K., \& Kokila, M.K. (2012) (2E)-Nmethyl-2-(3-phenylpropylidene) hydrazinecarbothioamide. Acta Crystallogr, E68:02842.

36. Krishna, P. M., \& Reddy, K. H. (2009). Synthesis, single crystal structure and DNA cleavage studies on first 4N-ethyl substituted three coordinate copper (I) complex of thiosemicarbazone. Inorg. Chim. Acta, 362(11), 4185-4190.

37. Krishna, P. M., Reddy, K. H., Pandey, J. P., \& Siddavattam, D. (2008). Synthesis, characterization, DNA binding and nuclease activity of binuclear copper (II) complexes of cuminaldehyde thiosemicarbazones. Transition Met. Chem., 33(5), 661-668.

38. Skrzypek, A., Matysiak, J., Niewiadomy, A., Bajda, M., \& Szymański, P. (2013). Synthesis and biological evaluation of 1, 3, 4-thiadiazole analogues as novel AChE and BuChE inhibitors. Eur. J. Med. Chem., 62, 311-319.

39. Rehman, S. U., Sarwar, T., Husain, M. A., Ishqi, H. M., \& Tabish, M. (2015). Studying noncovalent drug-DNA interactions. Arch. Biochem. Biophy., 576, 49-60.

40. Ozluer, C., \& Kara, H. E. S. (2014). In vitro DNA binding studies of anticancer drug idarubicin using spectroscopic techniques. J. Photochem. Photobiol.: B: Biology, 138, 36-42.

41. Hajian, R., Ekhlasi, E., \& Daneshvar, R. (2012). Spectroscopic and electrochemical studies on the interaction of epirubicin with fish sperm DNA. J. Chem., 9(3), 1587-1598.

42. Zhou, J. H., Xia, S. Q., Chen, J. R., Wang, X. S., Zhang, B. W., Zhang, H. J., ... \& Zhang, J. P. (2004). Surface binding and improved photodamage of the lanthanum ion complex of hypocrellin A to calf thymus DNA. J. Photochem. Photobiol.: A, 165(1-3), 143-147.

43. Zhang, Q. Q., Zhang, F., Wang, W. G., \& Wang, X. L. (2006). Synthesis, crystal structure and DNA binding studies of a binuclear copper (II) complex with phenanthroline. J. Inorg. Biochem., 100(8), 1344-1352.

44. Song, Y. F., \& Yang, P. (2001). Mononuclear tetrapyrido [3, 2-a: 2', 3'-c: 3", 2"-h: 2"', 3"'-j] phenazine (tpphz) cobalt complex. Polyhedron, 20(6), 501-506.

45. Han, M. J., Duan, Z. M., Hao, Q., Zheng, S. Z., \& Wang, K. Z. (2007). Molecular light switches 
for calf thymus DNA based on three Ru (II) bipyridyl complexes with variations of heteroatoms. $J$. Phy. Chem. C, 111(44), 16577-16585.

46. Nayab, P. S., Pulaganti, M., Chitta, S. K., Abid, M., \& Uddin, R. (2015). Evaluation of DNA binding, radicals scavenging and antimicrobial studies of newly synthesized N-substituted naphthalimides: spectroscopic and molecular docking investigations. J. Fluoresc., 25(6), 19051920.

47. Lakowicz, J.R. (2006). Principles of Fluorescence Spectroscopy. $3^{\text {rd }}$ ed., Springer, Berlin, 278282.

48. Ling, X., Zhong, W., Huang, Q., \& Ni, K. (2008). Spectroscopic studies on the interaction of pazufloxacin with calf thymus DNA. J. Photochem. Photobiol. B, Biology, 93(3), 172-176.

49. Sarwar, T., Husain, M. A., Rehman, S. U., Ishqi, H. M., \& Tabish, M. (2015). Multi-spectroscopic and molecular modelling studies on the interaction of esculetin with calf thymus DNA. Molecular BioSystems, 11(2), 522-531.

50. Panchangam, M. K. (2017). Synthesis, structural characterization and DNA studies of trivalent cobalt complexes of (2E)-4N-substituted-2-[4-(propan-2-yl) benzylidene] hydrazinecarbothioamide. Mediterranean J. Chem., 6(3), 88-97.

51. Marmur, J. (1961). A procedure for the isolation of deoxyribonucleic acid from microorganisms. J. Mol. Biol., 3(2), 208-IN1.

52. Reichmann, M. E., Rice, S. A., Thomas, C. A., \& Doty, P. (1954). A further examination of the molecular weight and size of desoxypentose nucleic acid. J. Am. Chem. Soc., 76(11), 3047-3053.

53. Wolfe, A., Shimer Jr, G. H., \& Meehan, T. (1987). Polycyclic aromatic hydrocarbons physically intercalate into duplex regions of denatured DNA. BioChem., 26(20), 6392-6396.

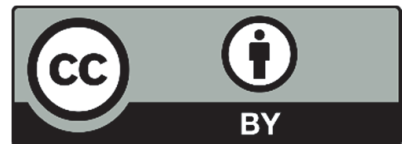

(C) 2019 by the authors; licensee Growing Science, Canada. This is an open access article distributed under the terms and conditions of the Creative Commons Attribution (CC-BY) license (http://creativecommons.org/licenses/by/4.0/). 